\title{
THE
}

\section{Independence day: Post-fledging movements and behavior of adult Eastern Towhees (Pipilo erythrophthalmus) in landscapes managed for American Woodcock (Scolopax minor)}

Stephen J. Brenner

University of Rhode Island, sjbrenner@uri.edu

Scott R. McWilliams

University of Rhode Island, srmcwilliams@uri.edu

Follow this and additional works at: https://digitalcommons.uri.edu/nrs_facpubs

The University of Rhode Island Faculty have made this article openly available.

Please let us know how Open Access to this research benefits you.

This is a pre-publication author manuscript of the final, published article.

Terms of Use

This article is made available under the terms and conditions applicable towards Open Access

Policy Articles, as set forth in our Terms of Use.

\section{Citation/Publisher Attribution}

Brenner, S. J., \& McWilliams, S. R. Independence day: Post-fledging movements and behavior of adult Eastern Towhees (Pipilo erythrophthalmus) in landscapes managed for American Woodcock (Scolopax minor). The Wilson Journal of Ornithology, 131(4), 796-806. doi: 10.1676/1559-4491-131.4.796 Available at: https://doi.org/10.1676/1559-4491-131.4.796

This Article is brought to you for free and open access by the Natural Resources Science at DigitalCommons@URI. It has been accepted for inclusion in Natural Resources Science Faculty Publications by an authorized administrator of DigitalCommons@URI. For more information, please contact digitalcommons-group@uri.edu. 
RRH: Brenner and McWilliams • Adult post-fledging behavior of towhees

\title{
Independence day: Post-fledging movements and behavior of adult Eastern Towhees (Pipilo erythrophthalmus) in landscapes managed for American Woodcock (Scolopax minor)
}

\author{
Stephen J. Brenner ${ }^{1 *}$ and Scott R. McWilliams ${ }^{1}$ \\ ${ }^{1}$ Department of Natural Resource Science, University of Rhode Island, Kingston, RI, \\ USA \\ * Corresponding author: sjbrenner@uri.edu
}

\begin{abstract}
Umbrella species management offers a potential solution to the financial and logistical challenges of managing for the many declining species in earlysuccessional forests, a habitat that is also critical for many mature and young forest songbird species during the post-fledging and post-breeding period. We investigated the movements of adult Eastern Towhees (Pipilo erythrophthalmus) during the post-fledging period in $4 \mathrm{~km}^{2}$ landscapes managed for American Woodcock (Scolopax minor), a popular umbrella species candidate for young forest management. Home range size (mean $=2.8$ ha, SE 0.33 ) did not differ during the post-fledging period between adult towhees inhabiting landscapes designated as high-likelihood (HL) or low-likelihood (LL) of woodcock use. Adults moved distances of $\sim 37-47 \mathrm{~m}$ per day during the first 3 weeks of the post-fledging period and this did not differ between the 2 landscapes. In contrast, once their young became independent, adults moved longer distances in HL compared to LL landscapes (49.5 m [SE 2.9] and $36.7 \mathrm{~m}$ [SE 3.6], respectively) and these distances increased with home range size and patch size. Landscape features within $100 \mathrm{~m}$ of the towhee home range best explained variation in towhee movement distance. Young forest habitat was also the predominant forest type used by adult towhees caring for fledglings throughout the post-fledging period. These results suggest that early successional forest management for woodcock can provide effective breeding habitat for towhees, but likely at a smaller spatial scale than typically managed for woodcock. Received 31 March 2018. Accepted 27 November 2018.
\end{abstract}

Key words: adult movements, American Woodcock, Eastern Towhee, independence, post-fledging, umbrella species management

Land managers and conservationists frequently face the challenge of using limited resources while having to manage for multiple species. Umbrella species management can offer an efficient solution to such challenges because land management focused on a single "umbrella" species can simultaneously benefit many co-occurring species (Lambeck 1997, Simberloff 1998, Fleishman et al. 2001) while also elevating the funding potential and resource allocation for the focal species of interest (Andelman and Fagan 2000, Kellert 2012, Fourcade et al. 2017). Game bird species are popular candidates for umbrella species status because they are usually charismatic species that attract 
opportunities for financial gains through hunting revenues, there are often established management histories and prescriptions, and there are usually potential benefits of this management for nongame species (Suter et al. 2002, Masse et al. 2015).

Most avian studies that assess habitat quality in areas principally managed for game species focus on songbird occupancy and density during the breeding period when males are territorial (Suter et al. 2002, Roberge and Angelstam 2004, Johnson 2007). Other studies on nontarget songbirds also measure nest success and survival of young (Herkert et al. 2003, Campbell et al. 2007, Chandler et al. 2009). Although the results of such studies can help determine whether certain land management techniques benefit these nontarget songbird species, the territory establishment and nesting period constitute an important but relatively small portion of a migratory songbird's breeding cycle. Recent work has focused on the post-fledging period because survival during this period often strongly influences population dynamics (Vega Rivera et al. 1998, Streby and Andersen 2011, Cox et al. 2014, Vernasco et al. 2018), and because movements and habitat use during the post-fledging period are often different than at other times of the annual cycle (Chandler et al. 2012, Burke et al. 2017).

Landscape-level factors may affect spatial movement, habitat use, and nest success in songbirds (Saab 1999, MacFaden and Capen 2002, Okada et al. 2017) and landscape-level features could lead to the different patterns of use or avoidance of certain managed areas at different life stages (Ahlering and Faaborg 2006, Fahrig 2013). Few studies of nontarget songbird species have characterized the spatial movements of adults during the post-fledging stage (Bayne and Hobson 2001, Vitz and Rodewald 2006). Even though adult survival rate is usually high during this time (Krementz et al. 2000, Sillett and Holmes 2002), there are potential changes in habitat use as young become more mobile and independent. This period constitutes a large portion of time that many migratory birds will spend in management areas and may influence predation risk or habitat selection (Vitz and Rodewald 2007, Streby 2016). During the post-fledging stage, adults are not anchored to a nest with immobile young that require frequent feedings, protection, and thermoregulation (van Overveld et al. 2017), and thus the effect of landscape-level factors on adult movement patterns and space use may be especially prominent during this stage with more independence (Bayne and Hobson 2001).

We studied the movement patterns and habitat use of adult Eastern Towhees (Pipilo erythrophthalmus) during the post-fledging period while they inhabited areas actively managed for American Woodcock (Scolopax minor). The loss of early successional forests throughout southern New England (Schlossberg and King 2007, Buffum et al. 2011) has been associated with the declines of popular upland game bird species such as Ruffed Grouse (Bonasa umbellus) and American Woodcock, as well as many nongame bird species (Askins 2001, King and Byers 2002). Early successional forests have been shown to be important for songbirds that inhabit mature forests during the nesting period, such as Ovenbird (Seiurus aurocapilla) and Wood Thrush (Hylocichla mustelina), which move to early successional forests during the post-fledging stage (Vega Rivera et al. 1998, Vitz and Rodewald 2010, Chandler et al. 2012). Early successional forest management in New England has focused on creating singing grounds, roosting fields, and nesting habitat for American Woodcock (hereafter, "woodcock") via forest clearcuts and active brush-thinning and mowing operations (Williamson 2010, Masse et al. 2014). Previous research has identified woodcock as a good umbrella species 
candidate for other early successional forest species (Bakermans et al. 2015, Masse et al. 2015), but little work has explored the impacts of this land management on the spatial ecology of songbirds within landscapes managed for woodcock.

The Eastern Towhee is a common but declining songbird in the Northeast US that inhabits scrub, edge, and young forest habitats (Greenlaw 2015). Eastern Towhees (hereafter, "towhee") are an excellent species to study in habitat managed for woodcock because they are found during the breeding season predominantly in early-successional and young forests, occur simultaneously in the region with woodcock (Fleishman et al. 2001), and have demonstrated quick responses to management in previous studies (Yahner 2003). Towhee occurrence in managed shrublands in southern New England is influenced by certain landscape-level features such as overall shrubland area (Askins et al. 2007). However, no previous study has investigated the movement behavior of adult towhees during the post-fledging period when adults with fledglings are no longer tethered to their nest. Our primary objective was to compare home range size, habitat use, and movement patterns of adult towhees during the post-fledging period in state-managed areas that differed in their likelihood of use by woodcock (high- or low-likelihood of use). If woodcock serve as an effective umbrella species for towhees and other scrubgeneralist songbirds, then we would expect towhees to positively respond to forest management targeted for woodcock.

\section{Methods}

\section{Study area}

All research was conducted within central and southern Rhode Island in Washington and Kent counties. Early successional forest management in these state-owned areas has focused in part on creating singing grounds, roosting fields, and nesting habitat for woodcock via forest clearcuts (Masse et al. 2014). The sites where we searched for and eventually tracked Eastern Towhees were the same state-managed young forests that were selected for a separate, simultaneous study on American Woodcock habitat selection (Brenner et al. 2019). We identified 6 landscapes $\left(4 \mathrm{~km}^{2}\right)$ of 2 types: high- and low-likelihood of use by woodcock. Each of these landscapes was centered on an area of managed early successional forest at which we confirmed woodcock breeding activity. These centers were recent ( $<15 \mathrm{yr}$ ) forest clearcuts $0.76-10$ ha in size. In high-likelihood of woodcock use landscapes (hereafter, "HL landscapes"), there was more early successional forest/upland shrub, more hydric soils, and generally more mature deciduous or mixed forest (Masse et al. 2014, Brenner et al. 2019). In low-likelihood of woodcock use landscapes (hereafter, "LL landscapes"), there was more mature coniferous forest and relatively less early successional forest/upland shrub. This landscape size $\left(4 \mathrm{~km}^{2}\right)$ was chosen to match the recommended sizes for woodcock management in the Northeast (Williamson 2010, Masse et al. 2014). Our 3 HL landscapes were Great Swamp North $\left(41^{\circ} 28^{\prime} 24^{\prime \prime} \mathrm{N}, 71^{\circ} 34^{\prime} 19^{\prime \prime} \mathrm{W}\right)$, Great Swamp South $\left(41^{\circ} 27^{\prime} 10^{\prime \prime} \mathrm{N}, 71^{\circ} 35^{\prime} 27^{\prime \prime} \mathrm{W}\right)$, and Tillinghast Pond $\left(41^{\circ} 38^{\prime} 55^{\prime \prime} \mathrm{N}, 71^{\circ} 45^{\prime} 40^{\prime \prime} \mathrm{W}\right)$. Our 3 LL landscapes were Big River East $\left(41^{\circ} 38^{\prime} 19^{\prime \prime} \mathrm{N}, 71^{\circ} 34^{\prime} 40^{\prime \prime} \mathrm{W}\right)$, Arcadia: Midway $\left(41^{\circ} 38^{\prime} 20^{\prime \prime} \mathrm{N}, 71^{\circ} 34^{\prime} 39^{\prime \prime} \mathrm{W}\right)$, and Arcadia: Pine Top $\left(41^{\circ} 36^{\prime} 50^{\prime \prime} \mathrm{N}, 71^{\circ} 46^{\prime} 26^{\prime \prime} \mathrm{W}\right)$.

\section{Towhee netting and tracking}


We searched for territorial towhees from 25 May to 5 August 2016 and 2017 and limited our search to areas within the 6 focal landscapes that were young forest and upland scrub, including recent forest clearcuts, adjacent powerline right-of-ways, and areas with active brush thinning or mowing to maintain woodcock singing grounds. We opportunistically searched for towhee territories by walking within and along the edge $(<50 \mathrm{~m})$ of these managed young forest patches and looked for evidence of breeding activity (carrying nest material, carrying food, or caring for recently fledged young). When possible, we would locate nests and monitor nests until fledge or failure (Martin and Geupel 1993).

We used conspecific audio playback and mist nets to attract and capture territorial adult towhees or adults with nests or fledglings from 25 May to 5 August. We captured and tracked only 1 of the 2 adults that were caring for the same brood and did not target any particular sex during capture. After ageing, sexing, and taking basic morphometric measurements (Pyle 1997), we gave each individual a unique plastic color-band combination in addition to a standard USGS aluminum band. Advanced Telemetry Systems (Isanti, Michigan, USA) model A2400 VHF radio transmitter (weight $=0.71 \mathrm{~g}$, $<2 \%$ body mass) were affixed to adult towhees using an elastic modified leg-loop harness design (Rappole and Tipton 1991), with size of harness based on the body mass of the bird (Naef-Daenzer 2007).

We used a 3-element Yagi antenna and ATS R2000 series receiver to track radiomarked adult towhees. Adults were located by first tracking individual signals with receivers to within 5-15 $\mathrm{m}$ of a bird. Observers would then visually search for and record each individual's color bands and record the GPS location of each individual. Once located, a 20 min observation period followed to determine breeding stage, if the adults were caring for young, and the degree of parental care activity (Table 1). Some birds $(n=$ 3) lost their transmitters before the end of the breeding season but were still raising young. These birds were tracked using vocalizations and color band resights, with the same 20 min observation protocol as if tracking by VHF.

We tracked adults from the first week after their young fledged from the nest (0-6 $\mathrm{d}$ after fledge) until at least 3 weeks after fledging or as long as the bird was on radio (23-54 d). We attempted to track each individual at least 3 times a week so we recorded at least 15 locations throughout the post-fledging period. We gathered one location per day for each individual to use in home range and movement analysis, and we stratified our sampling times each day to capture a majority of the active daytime hours for songbirds $(0530 \mathrm{~h}-1500 \mathrm{~h}$ EDT). Only adults that were able to successfully raise at least one towhee fledgling were included in the statistical analysis of home range size and movement patterns. We observed 2 instances of double brooding by adults in our study after they successfully raised at least one fledgling during their first nest attempt. Both failed on their subsequent nesting attempts. Although we tracked these individuals throughout the summer, we limited our spatial analysis to only those locations used before the second nest was initiated.

\section{Determining age of recently fledged young}

In cases where we discovered adults with young after the nestling period and during the first week (0-6 d) of fledging (14 of 31 individuals), we visually estimated the age of fledglings using plumage, locomotive, and behavioral cues (Table 1). These age estimates were based on the characteristics of known-age fledglings and previous work with 
fledgling songbirds (Sullivan 1988, Kershner et al. 2004, White and Faaborg 2008, Burke et al. 2017). Adults that we began tracking with young that were older than one week after fledging $(7+d)$ or for which we were unable to obtain 15+ GPS locations were not used in home range or movement analysis. To determine changes in movement patterns over time, we categorized the age of fledglings into 4 broad stages: early-fledgling (0-6 d), mid-fledgling (7-13 d), late-fledgling (14-20 d), and independence (21+d; Table 1). These stages captured the broad changes in fledgling development and changes in parental care during the approximately $20 \mathrm{~d}$ dependent period with young. Survival of young is relatively constant after $20 \mathrm{~d}$ (Cox et al. 2014) and we never observed adults accompanied by dependent young more than $21 \mathrm{~d}$ post-hatch. Any adults we captured and began tracking with young that did not clearly fit within these 4 stages were excluded from home range and movement analysis $(n=2)$.

\section{Statistical analysis}

We used kernel density methods (Worton 1989) within Geospatial Modeling Environment (Beyer 2013) to calculate diurnal post-fledging home ranges (95\% contour) for adult towhees. We specified a Gaussian kernel with likelihood bandwidth estimator as recommended in studies such as ours with a small number $(<50)$ of locations per individual (Horne and Garton 2006). For the home range and movement analyses, we gathered on average 21 points per individual (range: 16-31 points) for 31 adult towhees with accompanying fledgling(s). We used statewide land cover data (RIGIS 2012) in ArcGis 10.2 (ESRI, Redlands, California, USA) to estimate forest composition (\% young forest/scrub, mature coniferous forest, mature deciduous forest, mixed forest, and grassland/agriculture) within a given landscape size (i.e., 100, 250, 500, and 1,120 m) as well as the size of young forest patches (i.e., the managed areas where we searched for adults). To determine the scope of movement covered by adults during the 4 different stages of fledgling development, we measured the distances between sequential points that occurred within the same fledgling development stage (mean distance between daily locations; Bayne and Hobson 2001). We considered this measurement an indicator of the extent of space use during the different stages of the post-fledging period.

We used general linear models to test the effects of landscape type, sex, and young forest patch size on post-fledging home range size. We also used general linear models to determine the effect of the surrounding forest composition on home range size at 4 different landscape scales: the original $4 \mathrm{~km}^{2}$ woodcock landscapes $(1,120 \mathrm{~m}$ from the edge of the home range), and at 500, 250, and $100 \mathrm{~m}$ from the edge of the home range. We used linear mixed-effects models to determine if the distance per day traveled by adults during each of the 4 fledgling development stages depended on landscape type, sex, site, and year. We used the ID of each individual bird as a random effect to control for repeated measures, and Tukey post hoc testing using least-squared means to determine significance at $\alpha=0.05$ between groups at different stages. After determining that adult movements differed during the independence stage between birds in the 2 landscape types, we conducted 2 additional statistical analyses to discern what general breeding and landscape variables influenced the distances moved during this stage. We used general linear models to test the effect of woodcock landscape type and all combinations of sex, young forest patch size, and home range size on distance moved per day across the independence stage. We used general linear models to test the effects of 
surrounding forest composition at 4 different landscape scales on the distances moved during the independence stage. Given that the predominant habitat used by adults with fledglings was young forest/scrub, we used chi-squared test $\left(\chi^{2}\right)$ to compare proportions of adult locations in young forest between the 2 types of woodcock landscapes at each of the 4 fledgling development stages. All statistical testing was completed using R opensource software (version 3.3.2; www.r-project.org). Values are reported as means and SE. We used Akaike's Information Criteria (AIC) and Akaike weights $\left(\omega_{i}\right)$ to select the best model among competing models (Anderson et al. 2000).

\section{Results}

From 25 May to 5 August in 2016 and 2017, we captured, color banded, and affixed transmitters to 60 adult towhees. Of these, 31 adults ( 21 male, 10 female) provided a sufficient number of locations to be used in our analysis of home range size and habitat use during the post-fledging stage, and distance moved per day during each of the 4 stages of fledgling development. Nineteen of these birds were tracked in HL landscapes, and 12 birds were tracked in LL landscapes. Of the 29 adults captured but not used for home range and habitat use analysis, 10 adults successfully raised fledglings, but we either began tracking them after the first week of fledge, or we did not gather 15+ points throughout the season. Of the other 19 adults not used for home range or habitat use analysis, 10 adults were tracked but we could not confirm whether they successfully raised young to fledge or successfully nested at all, 8 adults attempted to nest but failed (sometimes in multiple attempts) during incubation, the nestling stage, or right before fledging, and one individual was depredated within one week of tracking.

\section{Home range and scope of movements in different woodcock landscapes}

Home range size of the 31 adults during the post-fledging period averaged 2.8 ha (SE 0.33 , range: $0.78-8.06 \mathrm{ha}$ ). There was no difference in post-fledging home range size for towhees in HL landscapes (3.09 ha, SE 0.43) compared to LL landscapes (2.37 ha, SE $0.49, F_{1,29}=1.18, P=0.285$; Fig. 1$)$. All 11 models to explain home range size had poor fit $\left(R^{2} \leq 0.122\right)$ and none of these models was significant $(P \geq 0.134)$.

The best model to explain the distances moved per day of adults during the postfledging period included fledgling development stage and landscape type. During the first 3 stages of fledgling development, there were no significant differences in the daily movement distances of adult towhees in the HL vs. LL landscapes (early fledging: $t=$ $0.2, P=0.858$; mid-fledging: $t=0.9, P=0.399$; late fledging: $t=0.9, P=0.375$; Fig. 2). However, during the independence stage, adult towhees in HL landscapes covered longer distances per day than adults in LL landscapes ( $t=2.1, P=0.045$; Fig. 2.). The 3 top models $(<2 \Delta$ AIC) to explain the differences in movement distances during the independence stage of fledgling development always included home range size and landscape type $\left(R^{2}=0.413, F_{2,28}=11.6, P \leq 0.001\right.$; Table $\left.2 \mathrm{~A}\right)$, with patch size and sex included in 2 of these 3 models $\left(R^{2}=0.388\right.$ [Patch and Sex] $R^{2}=0.387$ [Sex]; Table 2A). Distances were longer in HL compared to LL landscapes and increased with home range size, patch size, and for males. The highest-ranked model that incorporated landscape composition features was forest composition within $100 \mathrm{~m}$ of the post-fledging home range (Table 2B), although this model did not explain much of the variation in movement distance of adult towhees $\left(R^{2}=0.141, F_{5,25}=2.0, P=0.119\right)$. 
Most (54.5\%) of the adult towhee locations collected throughout the post-fledging period occurred within young forest/scrub, with mature upland forest types (26.2\%) and grasslands/fields (14.6\%) accounting for the majority of the remaining habitat types. Adult towhees in HL landscapes compared to LL landscapes used marginally less young forest/scrub during the early-fledgling stage $\left(51.7 \%\right.$ in HL and $69.3 \%$ in LL, $\chi^{2}=2.9$, df $=1, P=0.086)$ and mid-fledgling stage (43\% in HL and $60 \%$ in LL, $\chi^{2}=3.4$, $\mathrm{df}=1, P=$ $0.063)$. There was no difference in young forest/scrub use between adults in different landscape types during the late-fledgling $\left(55 \%\right.$ in $\mathrm{HL}$ and $60 \%$ in $\mathrm{LL}, \chi^{2}=0.1 \mathrm{df}=1, P$ $=0.705)$ or independence stage $\left(55.4 \%\right.$ in $\mathrm{HL}$ and $60 \%$ in $\mathrm{LL}, \chi^{2}=0.5$, df $=1, P=$ $0.467)$.

\section{Discussion \\ Potential impact of umbrella species management for woodcock on adult towhees during the post-fledging period}

Overall, adult towhee home range size and distance moved per day prior to independence were similar between landscapes that differed in their suitability for woodcock. These results combined with the fact that young forest habitat was the predominant forest type used by adult towhees caring for fledglings, and that this same young forest habitat was created in the region to promote woodcock use, suggest that a broad mix of earlysuccessional forest management can provide breeding and post-breeding habitat for towhees.

Woodcock require several different forest types and habitats during the breeding and post-breeding period in order to thrive. Woodcock use clearcuts and open fields for displaying and roosting, young forest and scrub for nesting, and moist soils with enough vegetative cover for safe diurnal feeding (Dessecker and McAuley 2001, Masse et al. 2014). Many aspects of the movements and habitat use of woodcock differ from that of towhees, although they clearly both require early-successional forest during the breeding season. Recommended minimum patch size for young forest songbirds such as towhees in the Northeast is 0.6-1 ha (Askins et al. 2007, Schlossberg and King 2007), which was consistent with the smallest early-successional forest patch size ( $0.76 \mathrm{ha})$ used by breeding towhees in our study. Thus, both the size and type of habitat needed for breeding towhees was available in the state-owned areas managed for woodcock that we studied. Adequate vegetation to provide nesting cover, protection for fledged young from predators, and adequate forage (Stoleson 2013, Greenlaw 2015) are necessary for scrubgeneralist towhees to successfully raise young, and this vegetation was available in both landscapes managed for woodcock and resulted in similar post-fledgling home range sizes and movements. However, we need better information about how such land management affects productivity (i.e., nest success, clutch and brood size), recruitment, and survival of towhees before we can determine if focused management for woodcock also enhances towhee populations.

\section{Behavioral shift for adult towhees once young reached independence}

We did not observe significant changes in the scope of adult movements while they were still caring for their fledglings, even as young became more mobile in the mid- and latefledging stages (Fig. 2). However, when parental care ceased during the independence stage, adults in HL landscapes traveled across greater distances per day than adults in LL 
landscapes (Fig. 2) Adult towhees consistently used primarily young-forest habitat throughout the post-fledging and independence stages. Previous work with adult Ovenbirds during the post-fledging period also noted a lack of difference in home range size and movements between birds in different landscapes, but did observe differences in space use between adults with and without young (Bayne and Hobson 2001). We observed all adults essentially cease parental care about $20 \mathrm{~d}$ after their young fledged. This independence period is likely an important time for adults that have successfully raised young because it is when post-breeding adults must focus on individual maintenance and recovery of condition before migration (Vitz and Rodewald 2007).

Adult towhees that inhabited HL landscapes moved over longer distances during the independence stage $(21+\mathrm{d}$ after fledge) than those inhabiting LL landscapes. The extent of these movements during the independence stage was most related to home range size, size of young-forest patches, and forest composition within $100 \mathrm{~m}$ of the towhee home range. Previous research on shrubland bird communities in the state also noted the positive impact of habitat features such as wetland shrubland within $100 \mathrm{~m}$ of territorial males (Buffum and McKinney 2014), further indicating that landscape impacts on the movement of songbirds in early-successional forests likely occurs at a spatial scale much smaller than that typically managed for woodcock.

\section{Woodcock as an umbrella species}

Our results suggest that management for woodcock singing and nesting grounds in forested landscapes in southern New England can provide breeding and post-breeding habitat for towhees, mainly through the creation of new early-successional forest, shrub, and dense understory habitat. However, forest management for woodcock in the northeastern United States typically occurs at a larger (at least $4 \mathrm{~km}^{2}$ ) spatial scale (Williamson 2010, Masse et al. 2014) than what we found was used by towhees during the post-fledging and independence stages of their life history. Adult towhee postfledging home range sizes did not differ between HL and LL landscapes, whereas male woodcock behavior differed in these same $4 \mathrm{~km}^{2}$ landscapes in a previous study (Brenner et al. 2019). Thus, while both species utilize early-successional forests, they are likely responding to habitat features at different spatial scales (Kramer et al. 2019).

Towhees are part of a particular guild of generalist shrubland songbirds that forage primarily on the ground and rely upon forest understory (Greenlaw 2015, Langlois 2017). However, other declining early-successional forest/shrubland songbirds have more specific habitat requirements than the relatively ubiquitous towhee (DeGraaf and Yamasaki 2003, Leuenberger et al. 2017) and have been shown to respond differently to landscape- and local-scale features than the towhee (Askins et al. 2007, 2012). A particular forest management strategy focused on woodcock that benefits some earlysuccessional species in one region may not apply to other early-successional species in a different region. Thus, the ecology and habitat requirements of nontarget songbird species must be well understood before broad management recommendations are applied across taxa (Hale and Swearer 2017, Kramer et al. 2019). Studies that combine occupancy, reproductive, and spatial information for focal songbird species are needed to successfully refine umbrella species management in order to successfully manage at the appropriate spatial scale for the highest number of species. 
Acknowledgments

This study was funded through grants from the Rhode Island Agricultural Experiment Station, the Rhode Island Department of Environmental Management via the USFWS Wildlife and Sport Fisheries Restoration to RI project W23R (Job 1-12), and the URI Department of Natural Resource Science, College of Environmental and Life Sciences. All birds were captured under master bander permit \#22923 from the US Geological Survey Bird Banding Laboratory, and all research activities were approved by the University of Rhode Island Institutional Animal Care and Use Committee (\#AN10-02-

017). We would like to thank Brian Tefft for his logistical support and Scott Comings and The Nature Conservancy for granting land access. We would like to thank L. Douglas, M. Moniz, K. Blackmon, E. Gonzalez, R. Healey, and K. Tillinghast for their support in the field. We also thank Olivia DaRugna for banding support, fieldwork, and assistance with fledgling aging characteristics. This is contribution number 5472 of the Rhode Island Agricultural Experiment Station.

Literature cited

Ahlering M, Faaborg J. 2006. Avian habitat management meets conspecific atraction: If you build it, will they come? Auk 123:301-312.

Andelman SJ, Fagan WF. 2000. Umbrellas and flagships: Efficient conservation surrogates or expensive mistakes? Proceedings of the National Academy of Sciences USA 97:5954-5959.

Anderson DR, Burnham K, Thompson W. 2000. Null hypothesis testing: Problems, prevalence, and an alternative. Journal of Wildlife Management 64:912-923.

Askins RA. 2001. Sustaining biological diversity in early successional communities: The challange of managing unpopular habitats. Wildlife Society Bulletin 29:407-412.

Askins RA, Folsom-O'Keefe CM, Hardy MC. 2012. Effects of vegetation, corridor width and regional land use on early successional birds on powerline corridors. PLOS One 7:e31520.

Askins RA, Zuckerberg B, Novak L. 2007. Do the size and landscape context of forest openings influence the abundance and breeding success of shrubland songbirds in southern New England? Forest Ecology and Management 250:137-147.

Bakermans MH, Ziegler CL, Larkin JL. 2015. American Woodcock and Golden-winged Warbler abundance and associated vegetation in managed habitats. Northeastern Naturalist 22:690-703.

Bayne EM, Hobson KA. 2001. Movement patterns of adult male Ovenbirds during the post-fledging period in fragmented and forested boreal landscapes. Condor 103:343351.

Beyer HL. 2013. Geospatial Modelling Environment. Spatial Ecology, LLC. http://www.spatialecology.com/gme/

Brenner SJ, Buffum B, Tefft BR, McWilliams SR. 2019. Landscape context matters when American Woodcock select singing grounds: Results from a reciprocal transplant experiment. Condor: Ornithological Applications 121(1):duy005. https://doi.org/10.1093/condor/duy005

Buffum B, McKinney RA. 2014. Does proximity to wetland shrubland increase the habitat value for shrubland birds of small patches of upland shrubland in the northeastern United States? International Journal of Forestry Research 2014:1-9. 
Buffum B, McWilliams SR, August PV. 2011. A spatial analysis of forest management and its contribution to maintaining the extent of shrubland habitat in southern New England, United States. Forest Ecology and Management 262:1775-1785.

Burke AD, Thompson FR III, Faaborg J. 2017. Variation in early-successional habitat use among independent juvenile forest breeding birds. Wilson Journal of Ornithology 129:235-246.

Campbell SP, Witham JW, Hunter ML. 2007. Long-term effects of group-selection timber harvesting on abundance of forest birds. Conservation Biology 21:12181229.

Chandler RB, King DI, Chandler CC. 2009. Effects of management regime on the abundance and nest survival of shrubland birds in wildlife openings in northern New England, USA. Forest Ecology and Management 258:1669-1676.

Chandler CC, King DI, Chandler RB. 2012. Do mature forest birds prefer earlysuccessional habitat during the post-fledging period? Forest Ecology and Management 264:1-9.

Cox WA, Thompson FR, Cox AS, Faaborg J. 2014. Post-fledging survival in passerine birds and the value of post-fledging studies to conservation. Journal of Wildlife Management 78:183-193.

DeGraaf RM, Yamasaki M. 2003. Options for managing early-successional forest and shrubland bird habitats in the northeastern United States. Forest Ecology and Management 185:179-191.

Dessecker DR, McAuley DG. 2001. Importance of early successional habitat to Ruffed Grouse and American Woodcock. Wildlife Society Bulletin 29:456-465.

Fahrig L. 2013. Rethinking patch size and isolation effects: The habitat amount hypothesis. Journal of Biogeography 40:1649-1663.

Fleishman E, Murphy D, Blair R. 2001. Selecting effective umbrella species. Conservation in Practice 2:17-23.

Fourcade Y, Besnard AG, Secondi J. 2017. Evaluating interspecific niche overlaps in environmental and geographic spaces to assess the value of umbrella species. Journal of Avian Biology 48:1563-1574.

Greenlaw JS. 2015. Eastern Towhee (Pipilo erythrophthalmus), version 2.0. In: Rodewald PG, editor. Birds of North America. Ithaca (NY): Cornell Lab of Ornithology. https://doi.org/10.2173/bna.262

Hale R, Swearer SE. 2017. When good animals love bad restored habitats: How maladaptive habitat selection can constrain restoration. Journal of Applied Ecology 54:1478-1486.

Herkert JR, Reinking DL, Wiedenfeld DA, Winter M, Zimmerman JL, et al. 2003. Effects of prairie fragmentation on the nest success of breeding birds in the midcontinental United States. Conservation Biology 17:587-594.

Horne JS, Garton EO. 2006. Likelihood cross-validation versus least squares crossvalidation for choosing the smoothing parameter in kernel home-range analysis. Journal of Wildlife Management 70:641-648.

Johnson MD. 2007. Measuring habitat quality: A review. Condor 109:489-504.

Kellert SR. 2012. Social and perceptual factors in endangered species management. Journal of Wildlife Management 49:528-536.

Kershner EL, Walk JW, Warner RE. 2004. Postfledging movements and survival of 
juvenile Eastern Meadowlarks (Sturnella magna) in Illinois. Auk 121:1146-1154.

King DI, Byers BE. 2002. An evaluation of powerline rights-of-way as habitat for earlysuccessional shrubland birds. Wildlife Society Bulletin 30:868-874.

Kramer GR, Peterson SM, Daly KO, Streby HM, Andersen DE. 2019. Left out in the rain: comparing productivity of two associated species exposes a leak in the umbrella species concept. Biological Conservation 233:276-288.

Krementz DG, Powell LA, Carolina S. 2000. Breeding season demography and movements of Eastern Towhees at the Savannah River Site, South Carolina. Wilson Bulletin 112:243-248.

Lambeck R. 1997. Focal species: A multi-species umbrella for nature conservation. Conservation Biology 11:849-856.

Langlois LA. 2017. Effects of Marcellus Shale gas infrastructure on forest fragmentation and bird communities in northcentral Pennslyvania [dissertation]. State College (PA): The Pennsylvania State University.

Leuenberger W, McNeil DJ, Cohen J, Larkin JL. 2017. Characteristics of Golden-winged Warbler territories in plant communities associated with regenerating forest and abandoned agricultural fields. Journal of Field Ornithology 88:169-183.

MacFaden SW, Capen DE. 2002. Avian habitat relationships at multiple scales in a New England forest. Forest Science 48:243-253.

Martin TE, Geupel GR. 1993. Nest-monitoring plots: Methods for locating nests and monitoring success. Journal of Field Ornithology 64:507-519.

Masse RJ, Tefft BC, McWilliams SR. 2014. Multiscale habitat selection by a forestdwelling shorebird, the American Woodcock: Implications for forest management in southern New England, USA. Forest Ecology and Management 325:37-48.

Masse RJ, Tefft BC, McWilliams SR. 2015. Higher bird abundance and diversity where American Woodcock sing: Fringe benefits of managing forests for woodcock. Journal of Wildlife Management 79:1378-1384.

Naef-Daenzer B. 2007. An allometric function to fit leg-loop harnesses to terrestrial birds. Journal of Avian Biology 38:404-407.

Okada S, Lindenmayer DB, Wood JT, Crane MJ, Pierson JC. 2017. How does a transforming landscape influence bird breeding success? Landscape Ecology 32:1039-1048.

Pyle P. 1997. Identification guide to North American birds. Part I. Bolinas (CA): Slate Creek Press.

Rappole JH, Tipton AR. 1991. New harness design for attachment of radio transmitters to small passerines. Journal of Field Ornithology 62:335-337.

RIGIS. 2012. Forest Habitat. Rhode Island Geographic Information System Data Distribution System. Environmental Data Center, University of Rhode Island. www.rigis.org

Roberge J, Angelstam PER. 2004. Usefulness of the umbrella species concept as a conservation tool. Conservation Biology 18:76-85.

Saab V. 1999. Importance of spatial scale to habitat use by breeding birds in riparian forests: A hierarchical analysis. Ecological Applications 9:135-151.

Schlossberg S, King DI. 2007. Ecology and management of scrub-shrub birds in New England: A comprehensive review. Report to Natural Resources Conservation Service, Resource Inventory and Assessment Division, Beltsville, MD. 
Sillett ST, Holmes RT. 2002. Variation in survivorship of a migratory songbird throughout its annual cycle. Journal of Animal Ecology 71:296-308.

Simberloff D. 1998. Flagships, umbrellas, and keystones: Is single-species management passe in the landscape era? Biological Conservation 83:247-257.

Stoleson SH. 2013. Condition varies with habitat choice in postbreeding forest birds. Auk 130:417-428.

Streby HM. 2016. Survival and habitat use of fledgling Golden-winged Warblers in the western Great Lakes Region. In: Streby HM, Andersen DE, Buehler DA, editors. Golden-winged Warbler ecology, conservation, and habitat management. Studies in Avian Biology 49:127-140.

Streby HM, Andersen DE. 2011. Seasonal productivity in a population of migratory songbirds: Why nest data are not enough. Ecosphere 2:78.

Sullivan KA. 1988. Ontogeny of time budgets in Yellow-eyed Juncos: Adaptation to ecological constraints. Ecology 69:118-124.

Suter W, Graf RF, Hess R. 2002. Capercaillie (Tetrao urogallus) and avian biodiversity: Testing the umbrella-species concept. Conservation Biology 16:778-788.

van Overveld T, Vardakis M, Arvidsson L, Stolk K, Adriaensen F. 2017. Post-fledging family space use in Blue and Great tit: Similarities and species-specific behaviours. Journal of Avian Biology 48:333-338.

Vega Rivera JH, Rappole JH, Haas CA. 1998. Wood Thrush postfledging movements and habitat use in northern Virginia. Condor 100:69-78.

Vernasco BJ, Sillett TS, Marra PP, Ryder TB. 2018. Environmental predictors of nestling condition, postfledging movement, and postfledging survival in a migratory songbird, the Wood Thrush (Hylocichla mustelina). Auk: Ornithological Advances 135:15-24.

Vitz AC, Rodewald AD. 2006. Can regenerating clearcuts benefit mature-forest songbirds? An examination of post-breeding ecology. Biological Conservation 127:477-486.

Vitz AC, Rodewald AD. 2007. Vegetative and fruit resources as determinants of habitat use by mature-forest birds during the postbreeding period. Auk 124:494-507.

Vitz AC, Rodewald AD. 2010. Movements of fledgling Ovenbirds (Seiurus aurocapilla) and Worm-eating Warblers (Helmitheros vermivorum) within and beyond the natal home range. Auk 127:364-371.

White JD, Faaborg J. 2008. Post-fledging movement and spatial habitat-use patterns of juvenile Swainson's Thrushes. Wilson Journal of Ornithology 120:62-73.

Williamson SJ. 2010. American Woodcock: Habitat best management practices for the Northeast. In: Wildlife Insight 89. Washington (DC): US Department of Agriculture, Natural Resources Conservation Service.

Worton BJ. 1989. Kernel methods for estimating the utilization distribution in homerange studies. Ecology 70:164-168.

Yahner RH. 2003. Responses of bird communities to early successional habitat in a managed landscape. Wilson Bulletin 115:292-298. 
Table 1. General characteristics (i.e., appearance, mobility) of young Eastern Towhees and the parental care behavior of adult towhees during the 4 stages of the post-fledging period.

\begin{tabular}{|c|c|c|c|}
\hline Fledgling stage & $\begin{array}{l}\text { Appearance of } \\
\text { young }\end{array}$ & Mobility of young & $\begin{array}{c}\text { Parental care by adult } \\
\text { towhees }\end{array}$ \\
\hline $\begin{array}{l}\text { Early-fledgling } \\
\text { (0-6 days) }\end{array}$ & $\begin{array}{l}\text { Plumage is part } \\
\text { downy, spotted on } \\
\text { chest, drab colors. } \\
\text { Minimal tail visible. } \\
\text { Large, soft yellow } \\
\text { bill. }\end{array}$ & $\begin{array}{l}\text { Big legs with } \\
\text { developing flight } \\
\text { feathers. Cannot fly } \\
\text { above } 2-3 \mathrm{~m} \text {, } \\
\text { mostly limited to } \\
\text { ground or short } \\
\text { jumps. }\end{array}$ & $\begin{array}{l}\text { Adults very attentive. } \\
\text { Feeding frequently, } \\
\text { become very agitated } \\
\text { when observer near } \\
\text { fledgling(s). }\end{array}$ \\
\hline $\begin{array}{l}\text { Mid-fledgling } \\
\text { (7-13 days) }\end{array}$ & $\begin{array}{l}\text { Plumage is } \\
\text { developing, but still } \\
\text { mostly spotted } \\
\text { appearance with } \\
\text { some richer brown } \\
\text { tones developing. } \\
\text { Some tail visible. } \\
\text { Outer bill edges still } \\
\text { noticeably yellow. }\end{array}$ & $\begin{array}{l}\text { Able to make decent } \\
\text { lateral flights to } \\
\text { escape }(5-15 \mathrm{~m}) \text {. } \\
\text { Movement is more } \\
\text { fluid. Not able to } \\
\text { reach canopy or } \\
\text { high perches. }\end{array}$ & $\begin{array}{l}\text { Adults still feed regularly } \\
\text { and remain near young. } \\
\text { Less agitation when } \\
\text { observers near, but still } \\
\text { will call frequently. }\end{array}$ \\
\hline $\begin{array}{l}\text { Late-fledgling } \\
\text { (14-20 days) }\end{array}$ & $\begin{array}{l}\text { Spotting mostly } \\
\text { limited to face and } \\
\text { replaced by streaking } \\
\text { on body. Wings and } \\
\text { tail developing adult } \\
\text { colors (brown or } \\
\text { black). Full tail. }\end{array}$ & $\begin{array}{l}\text { Sustained flights } \\
\text { and confident } \\
\text { movers on the } \\
\text { ground. Able to } \\
\text { reach high perches } \\
\text { and canopy. }\end{array}$ & $\begin{array}{l}\text { Adults will still travel } \\
\text { with young, but limited } \\
\text { feedings and limited } \\
\text { agitation when observers } \\
\text { are near. }\end{array}$ \\
\hline $\begin{array}{l}\text { Independence } \\
(21+\text { days })\end{array}$ & $\begin{array}{l}\text { Body plumage buff } \\
\text { with faint streaks, } \\
\text { but wings and tail } \\
\text { fully adult in color. } \\
\text { Head usually buff } \\
\text { color. }\end{array}$ & $\begin{array}{l}\text { Fully capable in all } \\
\text { movements. Begins } \\
\text { to call like adult } \\
\text { after week } 4\end{array}$ & $\begin{array}{l}\text { Little to no parental care. } \\
\text { Adults will occasionally } \\
\text { move with young. }\end{array}$ \\
\hline
\end{tabular}

Table 2. (A) Highest-ranked general breeding models to explain the movement distances of adult Eastern Towhees during the independence stage of the post-fledging period. Variables included American Woodcock likelihood of use landscape (amwoLand), young forest patch size (patch), sex, and overall home range size (HR) during the post-fledging period. (B) Highest-ranked landscape composition models to explain the movement distances of adult towhees during the independence stage of the post-fledging period. Variables included percent young forest/shrub (PctShrub), percent mature coniferous forest (PctCon), percent mature deciduous forest (PctDec), percent mixed forest (PctMix), and percent grassland/agriculture (PctGrass) at 4 different landscape scales. 


\begin{tabular}{|cllll|}
\hline $\begin{array}{c}\text { (A) General } \\
\text { breeding } \\
\text { models }\end{array}$ & \multicolumn{1}{c}{ Variables } & AIC & $\Delta$ AIC & $\omega_{i}$ \\
\hline 1 & amwoLand, HR & 259.7 & 0 & 0.48 \\
\hline 2 & amwoLand, HR, Sex, patch & 260.8 & 1.1 & 0.27 \\
\hline 3 & amwoLand, HR, Sex & 261.6 & 1.9 & 0.19 \\
\hline 4 & amwoLand, HR, Sex, patch, year & 264.0 & 4.4 & 0.05 \\
\hline 5 & amwoLand & 274.8 & 15.1 & $<0.01$ \\
\hline $\begin{array}{c}\text { (B) } \\
\text { Landscape } \\
\text { composition } \\
\text { models }\end{array}$ & & & & \\
\hline Hab1 & $\begin{array}{l}\text { PctScrub,PctCon,PctDec,PctMix, } \\
\text { PctGrass @ 100 m }\end{array}$ & 274.0 & 0.00 & 0.81 \\
\hline Hab4 & $\begin{array}{l}\text { PctScrub,PctCon,PctDec,PctMix, } \\
\text { PctGrass @ 1,120 m }\end{array}$ & 277.9 & 3.9 & 0.12 \\
\hline Hab2 & $\begin{array}{l}\text { PctScrub,PctCon,PctDec,PctMix, } \\
\text { PctGrass @ 250 m }\end{array}$ & 279.6 & 5.5 & 0.05 \\
\hline Hab3 & $\begin{array}{l}\text { PctScrub,PctCon,PctDec,PctMix,PctGrass } \\
\text { @ 500 m }\end{array}$ & 281.3 & 7.3 & 0.02 \\
\hline & & & & \\
\hline
\end{tabular}




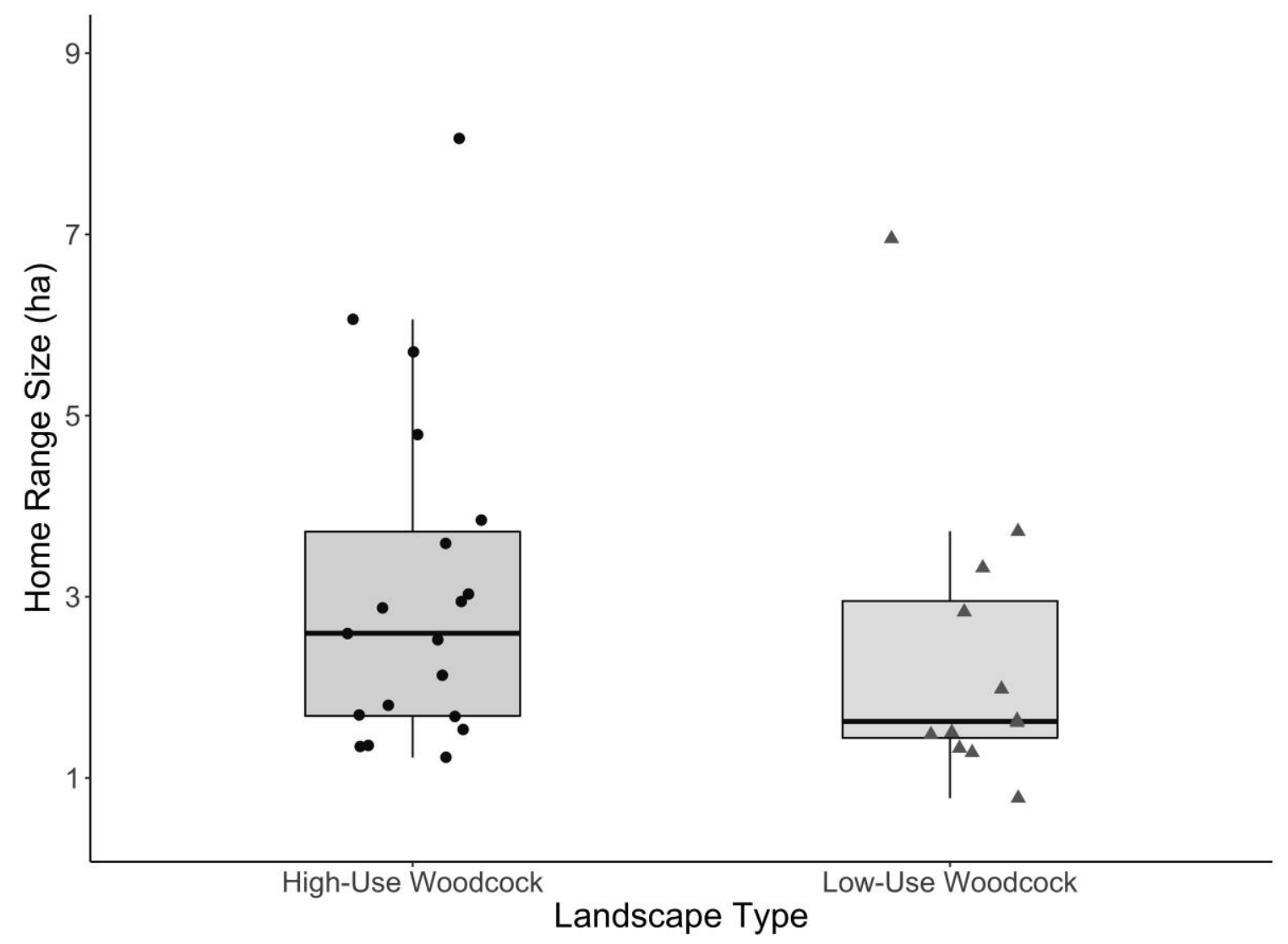

Figure 1. Home range size for adult Eastern Towhees during the post-fledging stage. Circles represent individual home range sizes for 19 towhees in high-likelihood of American Woodcock use landscapes. Triangles represent individual home range sizes for 12 towhees in low-likelihood of woodcock use landscapes. 


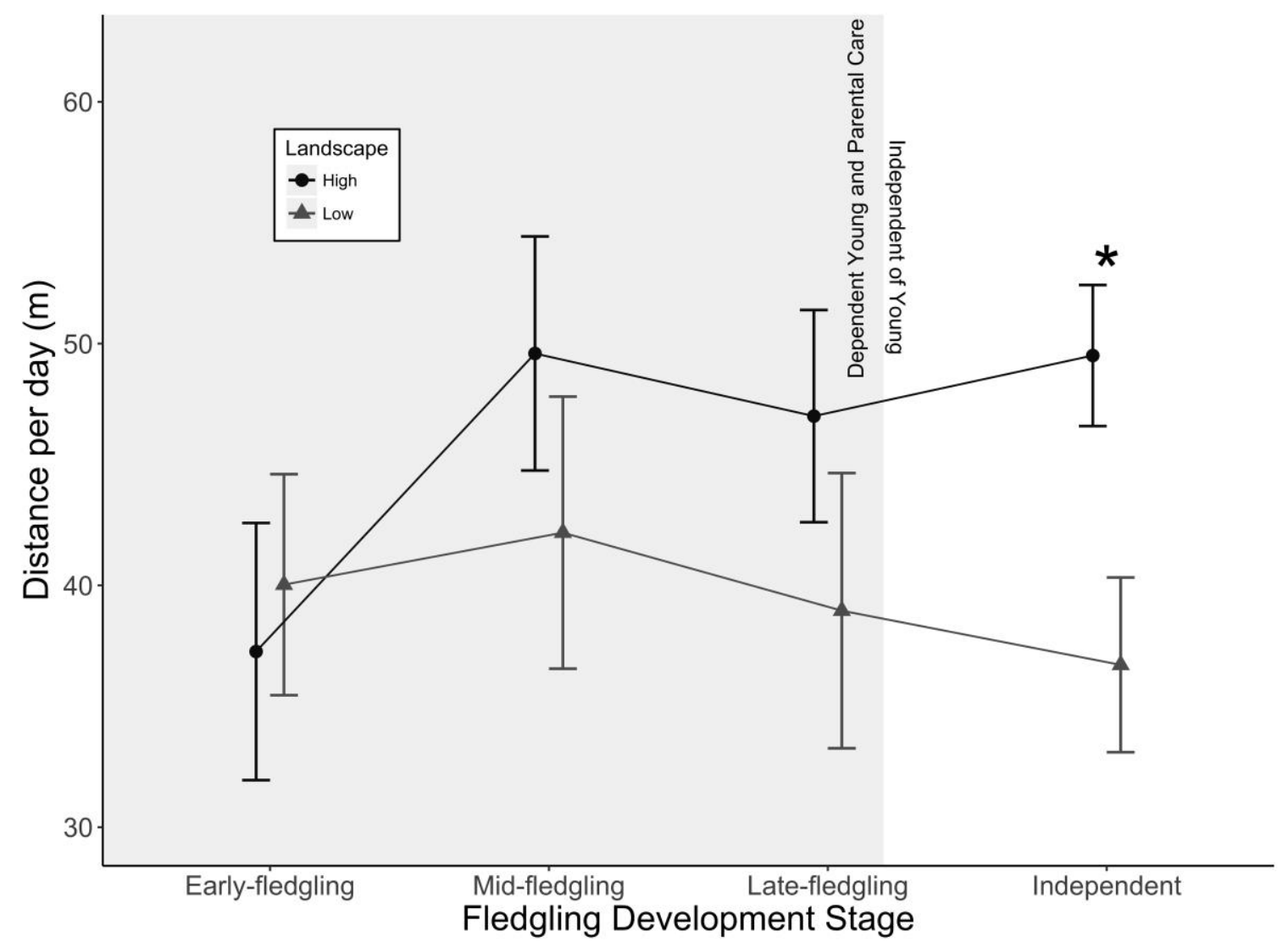

Figure 2. Daily movement distances (mean \pm SE) of adult towhees during 4 different fledgling development stages. Circles represent Eastern Towhees in high-likelihood of American Woodcock use landscapes, and triangles represent towhees in low-likelihood of woodcock use landscapes $(* P<0.05)$. 